\title{
ADMINISTRAÇÃO DIALÓGICA E UMA NOVA LEGITIMAÇÃO DOS ATOS ADMINISTRATIVOS: UMA REFLEXÃO DA DEMOCRACIA EM HABERMAS E OS OBSTÁCULOS DE UMA SOCIEDADE CIVIL MULTICULTURAL
}

\author{
Mateus Moura de Oliveira* \\ Eliezer Siqueira de Sousa Júnior ${ }^{* *}$
}

\section{RESUMO}

A administração dialógica, enquanto marco do direito público no período neoconstitucional, traz uma nova relação entre setor privado e Administração Pública, dando enfoque na participação ativa dos cidadãos no interesse público e na relação entre estes e o Estado. Por sua vez, esta nova sociedade civil, que emerge como forte atuante no cenário democrático, traz à análise o conceito de democracia de Habermas aplicado ao momento atual, culminando não só numa nova legitimidade dos atos administrativos, mas trazendo consigo os obstáculos de uma sociedade multicultural na busca do interesse público.

Palavras-chave: Administração Dialógica. Democracia. Habermas. Legitimidade. Sociedade Civil.

\section{DIALOGIC ADMINISTRATION AND A NEW LEGITIMATION OF ADMINISTRATIVE ACTS: A REFLEXION OF DEMOCRACY IN HABERMAS AND THE OBSTACLES OF A MULTICULTURAL CIVIL SOCIETY}

\begin{abstract}
The dialogic administration, while milestone of public rights in the neoconstitutional period, brings a new relation between the private sector and the Public Administration, giving emphasis to the active role of citizens in the public concern and in the relation between these and the State. In turn, this new civil society, which emerges as a strong active in the democractic scenario, brings in view the concept of democracy in Habermas applied to actual times, culminating not just in a consequent new legitimity of administrative acts, but bringing along obstacles of a multicultural society in search of public concern.
\end{abstract}

Keywords: Dialogic Administration. Democracy. Habermas. Legitimity. Civil Society.

\section{INTRODUÇÃO}

A Constituição Federal de 1988 trouxe consigo uma inovação na aplicação e interpretação das leis do ordenamento pátrio, erigindo os princípios e normas constitucionais a

\footnotetext{
* Mestre em Direito Público pela Universidade Federal de Sergipe (UFS). Especialista em Direito do Estado pela Faculdade Guanambi (BA). Membro do Grupo de Pesquisa Constitucionalismo, Cidadania e Concretização de Políticas Públicas. Email: matmouraadv@gmail.com

** Mestrando pela Universidade Federal de Sergipe em Constitucionalização do Direito. Membro do Grupo de Pesquisa Constitucionalismo, Cidadania e Concretização de Políticas Públicas. Juiz de Direito do Tribunal de Justiça do Estado de Sergipe. Email: eliezerjr@hotmail.com
} 
um novo patamar no tocante a sua irradiação às demais normas. Este novo cenário de neoconstitucionalismo implica mudanças em diversas áreas do Direito, em um então renovado diálogo principiológico e social.

No âmbito do Direito Administrativo, a administração dialógica inicia-se no Brasil com esta adoção de princípios constitucionais empregados às normas estatais. E é a partir deste ponto que se analisará uma quebra de paradigma na administração pública calcada no então renovado contato entre sociedade civil e poder público, bem como no posicionamento do controle social junto aos atos administrativos.

A relevância desta dialogia com a administração traz em Jürgen Habermas um importante e crucial expoente para justificar um discurso racional entre coletividade e Estado, com base em seus conceitos de democracia e sociedade civil. Estes irão, neste ínterim, conceder as ferramentas necessárias para coordenar e justificar a comunicação entre setor público e privado na busca de maior eficiência.

Em continuidade a esta nova importância da sociedade civil enquanto papel ativo e atuante na busca do interesse público, observar-se-á em paralelo um cenário social multicultural, o qual traz imbróglios para que as entidades da sociedade civil almejem, em um posterior momento, seus objetivos primários. A partir do ponto em que várias culturas sociais fazem-se presentes e atuantes na conjuntura pública, suas diferentes (e não poucas vezes divergentes) finalidades tendem a divergir, obstaculizando um melhor desempenho.

Para melhor entender isto, analisar-se-ão no primeiro capítulo as figuras da administração dialógica e do novo controle social sobre os atos administrativos, a fim de contextualizar o cenário em que surgem tais organizações da sociedade civil com mais moderna atuação.

Em sequência, ressaltam-se os conceitos de democracia e sociedade civil em Jürgen Habermas, de modo a justificar a atuação desta última no cenário atual, não só demonstrando sua viabilidade e aplicabilidade vigentes como também os principais exemplos em que atualmente se ocorre. É intuito também demonstrar a possibilidade de uma nova legitimidade dos atos administrativos, calcada no princípio do discurso e na comunicação racional entre Estado e sociedade civil, destacando ainda a importância dessas novas diretrizes no âmbito estatal.

Por fim, ao se apresentar uma sociedade multicultural e multifacetada, objetiva-se explorar os principais obstáculos de suas entidades na busca do interesse público comum, bem 
como as possibilidades para que tais entidades possam melhor desempenhar seu papel socialdemocrático.

Para tanto, utilizou-se uma pesquisa de cunho bibliográfico, com referências principais retiradas de bibliografias teórico-filosóficas sobre o tema e artigos científicos publicados, como também livros que traçam os principais pontos teóricos a lastrear o tema tratado.

\section{ADMINISTRAÇÃO DIALÓGICA E CONTROLE SOCIAL: NOVOS PARADIGMAS DA ADMINISTRAÇÃO PÚBLICA}

Figura recente que é no contexto de dirigismo estatal, a administração dialógica surge das crises estatais do período pós-segunda guerra, e aos poucos é incorporada em nosso ordenamento a partir da Constituição de 1988. Esta, por sua vez, numa linha neoconstitucionalista, passa a buscar a validade de suas normas não apenas num contexto formal, mas também material, com reflexos não só legais, mas éticos e sociais.

Nesta linha, a Constituição assume papel central, alcançando um novo patamar de real eficácia perante o caso concreto, e não mais mero mandado de otimização. A partir deste momento, seus efeitos e valores irradiam para todas as normas e codificações de um Estado, servindo como instrumento de garantia e validade.

Para o âmbito que aqui se trata, esta mudança trouxe de igual modo uma reviravolta na análise do Direito Administrativo, até então visto por um viés isolado, legalista, e pouco relacionado aos valores axiológicos constitucionais.

Sobre este ponto, tratou Gustavo Binenbojm:

Como agente condutor básico da superação de tais categorias jurídicas, erige-se
hodiernamente a ideia de constitucionalização do direito administrativo como
alternativa ao déficit teórico apontado nos itens anteriores, pela adoção do sistema
de direitos fundamentais e do sistema democrático qual vetores axiológicos -
traduzidos em princípios e regras constitucionais -a pautar a atuação da
Administração Pública. (BINENBOJM, 2006)

Este dito déficit teórico nasce da queda de um regime então vigente: supremacia do poder público sobre o privado de forma incondicional, com vantagens materiais e processuais; rígida legalidade administrativa, o que impedia manifestações autônomas de qualquer sorte; 
superioridade dos ditames administrativos e ausência de controle dos mesmos por outros poderes que não o próprio Legislativo (formulador da legalidade já citada); entre outros.

Em outras palavras, o Poder Público tinha como único concessor de legitimidade o próprio legislador que criava as regras e normas da Administração, e o Estado como único garantidor.

Quando se sai desta ótica e assumem-se os princípios constitucionais na Administração, muda-se também o paradigma. A supremacia do interesse público dá lugar a uma proporcionalidade casuística, com respeito à dignidade da pessoa humana. Os atos discricionários não são mais absolutos e passam a ser suscetíveis de apreciação pelo Judiciário. E a Administração descentraliza-se, dando novos papeis a instituições não diretamente hierarquizadas, mas ainda assim fiscalizadas pelo Estado. (OLIVEIRA, 2015)

É a partir deste ponto que surgem os primeiros indícios de uma nova administração pública, com base na dialogia. Isto é, no diálogo social com os cidadãos, a fim de que suas ações sejam justificadas e tomadas de acordo com o maior anseio dos principais interessados e atingidos. (PORTO, 2017)

Vários exemplos disto em nosso ordenamento podem ser apontados, como a ampliação da administração indireta, os diversos tipos de concessão de serviços públicos e as agências reguladoras surgidas no final da década de 1990. Porém, para o que se almeja este trabalho, crucial citar tão somente o terceiro setor da administração.

Tendo suas primeiras espécies surgido também ao final da década de 90, o terceiro setor nada mais é que entidades de natureza privada, que exercem atividades de interesse social e coletivo, com fins não-lucrativos.

Acerca deste surgimento, dispôs Marcelo Neves:

A atuação do poder público, no caso do estabelecimento de colaboração com as Organizações Sociais, dá-se de forma indireta, com o uso de instrumental jurídico para incentivar os particulares a executarem os serviços públicos sociais imanentes ao campo de atuação dessas entidades, máxime por meio do emprego de fomento. (NEVES, 2012)

E a importância destas entidades da sociedade civil está na mudança conceitual do controle social da administração e do papel destas entidades na administração dialógica. Aos poucos, o poder público deixa de buscar sua justificação na própria legalidade administrativa e na normatização para inserir-se no meio social, atentando-se às demandas públicas e dialogando com o meio social para buscar a melhor solução de vários conflitos. 
Tais entes do terceiro setor, neste ínterim, tornam-se o principal meio de comunicação do Estado para com o interesse público primário. É a partir desta dialogia organizada que se encontram os principais focos de atenção a serem combatidos e fomentados. E esta relação dialógica acaba não só por beneficiar como principalmente justificar os atos administrativos de maneira mais consistente.

Sobre a importância destas entidades, cita Eduardo Sabo Paes:

Assim, só recentemente começou-se a reconhecer a importância desse setor no âmbito da sociedade e da economia contemporâneas pela sua capacidade de mobilização de recursos humanos e materiais para o atendimento de importantes demandas sociais que, frequentemente, o Estado não tem condições de atender; pela sua capacidade de geração de empregos (principalmente nas sociedades mais desenvolvidas, onde os investimentos sociais são bem maiores); e pelo aspecto qualitativo, caracterizado pelo idealismo de suas atividades - enquanto participação democrática, exercício de cidadania e responsabilidade social. (PAES, 2013)

Assim, a partir de uma experimentação empírica do conflito social, quebra-se um paradigma pré-constitucional de atuação do Estado, pois a sociedade (organizada) assume o polo ativo contíguo à administração.

E frise-se também que esta atuação se encaixa na estratégia do Estado em não mais atuar diretamente em todos os setores sociais, mas apenas regulando-os e gerenciando-os. Lembre-se que, juntamente com o movimento neoconstitucionalista, o Estado Gerencial tomou parte em todos os principais países ocidentais do globo, pois o chamado Welfare State não mais sustentava todas as demandas de forma satisfatória. (MELLO, 2011)

O Estado Regulador vigente não permite mais que a ação direta do Poder Público se faça da maneira de outrora, sob pena de perda total do controle estatal. Paradoxalmente, a busca do controle total leva a controle algum.

Ou seja, a atuação destas entidades da sociedade civil, às quais se delega (involuntariamente) estas funções sociais, permite ao Estado uma maior concentração e eficiência nas atividades remanescentes. (GRAU, 2012)

Observa-se então a partir deste ponto duas conclusões principais. A um, que a conexão entre os setores público e privado se estreita de forma gradativa, favorecendo os dois lados em seus objetivos principais voltados ao interesse público. Isto graças a uma nova prática dialógica que permite se alcançar de forma mais célere e precisa os interesses sociais primários.

A dois, e seguindo este mesmo raciocínio dialógico, o controle social também muda de viés. Se antes havia um controle social apenas como "termômetro" dos atos já tomados, 
este deixa de ser apenas externo (isto é, do cidadão em vistas do Estado) e passa a ser também interno (o cidadão ao lado do Estado).

Assim, se há uma mudança de paradigmas no tratamento entre sociedade e poder público, pode-se enfim falar de uma sociedade civil atuante em discursos racionais e organizados, o que nos traz aos conceitos de Jürgen Habermas de democracia e sociedade civil.

\title{
3 DEMOCRACIA E SOCIEDADE CIVIL EM HABERMAS: REFLEXOS NO CENÁRIO PÚBLICO ATUAL
}

Jürgen Habermas, em seu livro "Direito e Democracia", assim conceituou a sociedade civil:

\begin{abstract}
A sociedade civil compõe-se de movimentos, organizações e associações, os quais captam os ecos dos problemas sociais que ressoam nas esferas privadas, condensamnos e os transmitem, a seguir, para a esfera pública política. O núcleo da sociedade civil forma uma espécie de associação que institucionaliza os discursos capazes de solucionar problemas, transformando-os em questões de interesse geral no quadro de esferas públicas. (HABERMAS, 2011)
\end{abstract}

Esta definição é um início do tópico suscitado em sua obra, a qual, embora tenha trazido este conceito ainda no início da década de 90, não se podia encontrar melhor definição.

A sociedade civil, no âmbito da Administração Pública, incumbe-se de preencher lacunas não abarcadas ou não alcançadas pelo Estado. Diante de um quadro omisso, a sociedade assume papel ativo na administração estatal, passando a tomar medidas capazes de solucionar os conflitos que porventura surjam em seu seio.

Assim, quebra-se um conceito de que o cidadão é sujeito passivo perante ações estatais, e o Estado, único garantidor do interesse público. Os preceitos democráticos não resumem-se a definir que todos escolham de forma igualitária seus representantes. Envolve, também, a atuação da esfera privada em todos os ramos da sociedade.

Não obstante, este novo conceito de cidadão não o exclui igualmente do polo passivo, mas sim o concede uma nova possibilidade. Isto é, o cidadão, enquanto detentor do direito a exercer seus direitos, não possui o dever de agir para o interesse público, mas sim uma viabilidade de atuar a sua vontade. (ARENDT, 1989) 
Exemplos práticos não faltam. Imagine-se, para tanto, uma comunidade periférica que verifica em seu meio um grande aumento no número de marginalizados ligados ao tráfico de entorpecentes. Esta periferia, longe do amparo estatal, busca mover-se para ela mesma solucionar um conflito que lhe atinge.

Ou imagine-se então, de forma mais simples, uma comunidade com alto grau de violência feita por menores. Esta mobiliza-se para criar soluções que deem amparo a estes jovens, cuidando de abarcá-los em programas desenvolvidos no próprio distrito.

Criam-se medidas sociais das mais diversas (apoio, acolhimento, assistência, entre outros), e o Estado, verificando posteriormente a eficiência destes atos, os apoia e fomenta. De fato, é muito mais rentável à máquina pública incentivar tais atividades do que reiniciá-las do zero, por mera logística administrativa e financeira.

É este papel que Habermas defende ao contextualizar a sociedade civil dentro de seu conceito maior do princípio do discurso ${ }^{\dagger}$ e da teoria do agir comunicativo. Para o autor, o discurso racional traz eficácia e legitimidade às ações do Estado, pois seu poder advém da prática comunicativa entre cidadãos que produzem entre si uma opinião estruturada. Sobre este ponto, afirma o autor:

Na linha da teoria do discurso, o princípio da soberania do povo significa que todo o poder político é deduzido do poder comunicativo dos cidadãos. O exercício do poder político orienta-se e se legitima pelas leis que os cidadãos criam para si mesmos numa formação de opinião e da vontade estruturada discursivamente. Quando se considera essa prática como um processo destinado a resolver problemas, descobrese que ela deve a sua força legitimadora a um processo democrático destinado a garantir um tratamento racional de questões políticas. (HABERMAS, 2012)

A democracia e princípio do discurso são conceitos multifacetados na obra de Habermas, não sendo intuito deste trabalho esgotá-los ou analisá-los em seus diversos aspectos, mesmo porque seria impossível em tão poucas linhas.

No entanto, em um de seus âmbitos, a democracia habermasiana possui expressa ligação com o papel da sociedade civil enquanto parte essencial da administração dialógica. Uma união de cidadãos que, de maneira racional e coordenada, trabalham não só para unissonamente definir seus representantes, mas tomar posição pioneira na definição de políticas e normas sociais ${ }^{+}$.

\footnotetext{
${ }^{\dagger}$ Sobre tal princípio, aponta o autor que o discurso racional serviria como validade de normas de ação àqueles diretamente atingidos, sendo assim não somente um procedimento institucional, mas social.

* Ainda sobre este ponto, Habermas cita que a tomada imperativa de decisões pelo poder administrativo fere os processos de argumentação, únicos capazes de fundamentar racionalmente as leis.
} 
Poder-se-ia dizer que, sob este prisma, a democracia de Habermas seria teórico e pouco prática, vez que seus críticos apontam-na como um sistema que não leva em consideração as próprias forças políticas opostas (que impediriam uma democracia substantiva) ou a alternância de poderes (que impede o consenso pleno, já que um grupo é eliminado do discurso).

Sobre isto, Marcos André de Barros, analisando a obra do autor, defende:

A isso Habermas responde que a democracia é um esforço de mediar conflitos de interesses políticos, porém sua realização implica o impedimento de dogmatismos e autoritarismos, bem como representa uma constante ampliação do espaço de realização de autonomia, aparentemente invisível em seu caráter procidemental. (BARROS, 2012)

Seguindo esta linha de pensamento, o escritor Richard Rorty, analisando criticamente a teoria de Habermas, propõe uma solução na discussão racional e democrática para que se chegue a um consenso, quando diz:

Deveríamos, em vez disso, admitir que não temos um terreno neutro onde nos colocar, quando defendemos tal política contra seus opositores. Se não admitirmos isso, penso que podemos ser corretamente acusados de tentar infiltrar nossas próprias práticas sociais na definição de algo universal e inelutável, porque pressuposto pelas práticas de todo e qualquer usuário de linguagem. Seria mais franco, e portanto melhor, dizer que a política democrática não pode apelar para essas pressuposições mais que a política antidemocrática, mas que ela não está absolutamente em maus lençóis por causa disso. (SOUZA, 2005)

Sendo assim, partindo-se do pressuposto esclarecido em tópico anterior, tem-se que as organizações da sociedade civil (terceiro setor) implicaram numa dita revolução nas relações com o Estado e aproximam-se assim do conceito habermasiano de democracia e sociedade civil.

Ao estimular o agir comunicativo, Habermas dispunha que apenas o dialógo racional e fundamentado pode dar prosseguimento a uma real democracia, sob pena de cairmos no totalitarismo. Portanto, se assumimos a sociedade civil como entidade organizada e focada no discurso público-privado, tem-se aí uma solução democrática e vindoura a fomentar as atividades de interesse público.

Isto porque, com a mudança de paradigma da Administração aqui discutido, toda legitimidade estatal provinda da própria legalidade, nos ditos de Habermas, consistia num paradoxo: o cidadão concede ao Estado a legitimidade necessária para criar leis, as quais por 


\section{ADMINISTRAÇÃO DIALÓGICA E UMA NOVA LEGITIMAÇÃO DOS ATOS \\ ADMINISTRATIVOS: UMA REFLEX ̃̃O DA DEMOCRACIA EM HA̧BERMAS E OS OBSTÁCULOS DE UMA SOCIEDADE CIVIL MULTICULTURAL}

sua vez legitimam os atos estatais. Ou seja, há um concreto contrasenso de legitimidade ${ }^{\S}$. (HABERMAS, 2012)

Ao passo em que a sociedade civil cresce gradativamente sua participação na esfera pública, igualmente cai por terra uma legitimação meramente legalista. Gustavo Binenbojm, neste contexto, justifica a administração dialógica como um meio de o Estado rever sua legitimidade enfraquecida:

O fomento à participação dos cidadãos em procedimentos administrativos - e, notadamente, nos processos regulatórios - tem sido uma das tentativas de recuperação do lastro de legitimidade da atuação da Administração Pública. Com efeito, à translação dos centros decisórios do Estado (do centro para a periferia) deve corresponder uma correlativa translação dos mecanismos de participação popular. Neste sentido, a governança por autoridades administrativas independentes desafia a teoria democrática à revisão de parte de seus instrumentos e ao desenvolvimento de novos modelos teóricos de autogoverno coletivo (BINENBOJM, 2006)

Com efeito, Peter Häberle dizia que a Constituição é um processo público de diálogo e conflito de noções indeterminadas. Este processo de diálogo, portanto, devem ser ações conjuntas entre ações públicas e agentes sociais, interpretando as normas da forma mais concreta e eficaz possível (BRANCO, 2010).

E a partir deste ponto indaga-se: se a legitimidade legalista cai por terra, por decerto esta lacuna deve ser preenchida por aquilo que assumiu seu lugar, ou seja, o diálogo públicoprivado entre sociedade civil e Estado.

Isto é, não se está mais falando que a administração dialógica é somente um meio eficaz de alcançar o interesse público primário. É verdadeira ferramenta obrigatória de legitimação.

E como esta legitimação será feita? De que modo este diálogo será organizado para que se justifique como ferramenta legitimadora?

O método discursivo de Habermas, baseado em sua teoria do agir comunicativo, que prevê um diálogo racional e sistematizado entre cidadãos, aponta ser o caminho mais viável para tanto. E o próprio autor justifica seu método ao dissertar uma conexão entre o princípio do discurso e a forma jurídica que resultam no princípio da democracia.

Por óbvio, não é um caminho fácil. Mesmo o próprio autor reconhece os riscos que uma democracia legitimada socialmente pode trazer, sob risco de uma instabilidade anárquica.

\footnotetext{
$\S$ Sobre este paradoxo, Habermas trata em capítulo do seu livro "Direito e Democracia" sua possível solução ao mesmo. Todavia, por não ser o objeto chave deste trabalho, faz-se aqui apenas a justa menção a suas conclusões para futuros estudos.
} 
Todavia, como o mesmo contrapõe, é o caminho mais legítimo para um meio democrático que se possa imaginar. (HABERMAS, 2014)

Assim, tal posicionamento indica uma evolução da administração dialógica, que parte de um método de maior eficiência para uma verdadeira legitimação do poder administrativo. Sem a comunicabilidade entre setores público e privado, inexiste lastro que justifique o ato administrativo como tal.

Não se fala, porém, que a anterior legitimidade concedida pelas normas vigentes se perde, mas sim se une. Concomitantemente, a norma legal, legitimidada em Habermas pelo discurso racional, volta ao mesmo em busca de uma nova legitimação de seus atos.

Abrindo um paralelo para o meio prático e social do Brasil, não podemos dizer que esta prática dialógica é plena. Não mais há que se falar sobre a necessidade ou não de organizações da sociedade civil. Estas já foram há muito reconhecidas como essenciais às práticas de um Estado Gerencial, e aqui reforça-se sua importância enquanto meio organizado para a discussão racional.

Porém, há uma via de mão dupla. Não se pode aguardar que tais entidades, representantes maiores (mas não únicas) da sociedade civil, venham a se estabelecer sem o devido apoio estatal. Muitas dessas organizações, situadas em meios periféricos, não conseguiram prosperar nos últimos anos devido à falta de suporte estatal logístico ou financeiro.

Regulamentações recentes, como é o caso da Lei 13.019/2014, preveem, além de novas práticas regulatórias, suporte administrativo e logístico a este ramo da sociedade civil. Todavia, esta medida normativa de natureza embrionária ainda não produziu os esperados frutos que se aguardam, justamente por prolongamento dos entes federativos na preparação necessária para se conceder tal suporte.

E diga-se, não é exclusividade de nosso Estado a desatenção com um setor social de tamanha importância. Veja-se para tanto as palavras do porto riquenho Ricardo Sol Arriaza:

\footnotetext{
Em este contexto, y lejos de superarse este proceso de construcción de ciudadanía basada en derecho y en reconocimiento/inclusión de sujetos sociales, es lógico que los índices de participación ciudadana y de su compromiso com la democracia, sean fluctuantes com tendencia debilitarse; en tanto dicho conpromisos se pretenden construir sobre la base de una convocatoria limitada a la asistencia a las urnas electorales para emitir un voto (ARRIAZA, 2012)
}

Ademais, muito embora o canal comunicativo entre Estado e sociedade abra-se em determinados momentos para situações de maior interesse social, muitas vezes se fecha 
quando não há um grande enfoque. Há uma "seletividade discursiva" que impede um agir comunicativo pleno.

Assim, o ponto-chave a se destacar nesta análise é que o discurso entre sociedade civil e Estado, muito embora criticado parcialmente pela sua eficiência prática, encontra em Habermas seu lastro teórico, pois seu princípio do discurso e teoria do agir comunicativo abre condições para que o diálogo racional ocorra.

E este diálogo, por sua vez, também dá lastro a uma legitimidade ora enfraquecida da Administração para com a sociedade, pois é através do contato e comunicação racional com os diretamente interessados que se observam os principais fundamentos legítimos para os atos administrativos.

\section{OBSTÁCULOS DE UMA SOCIEDADE CIVIL MULTICULTURAL}

Diante do quadro até então apresentado, conclui-se indubitavelmente pela relevância das entidades da sociedade civil no papel de legítimas e ativas partícipes na busca do interesse público. Porém, em uma perspectiva recente, e mais precisamente na realidade brasileira, a sociedade civil multicultural enfrenta barreiras que a impede de atuar de maneira plenamente efetiva.

Para se criar uma conjuntura mais coloquial, tem-se que as diversas organizações da sociedade civil brasileiras encontram-se numa atual posição de desamparo estatal. Não só financeiro, mas principalmente ideológico e logístico.

O desamparo ideológico vem de seu nascedouro. A organização da sociedade civil, que supostamente se origina de um anseio comunitário/coletivo, não se vê refletida no meio em que adveio. Ou melhor, a coletividade não vê naquilo que almejou a busca real e efetiva pela solução de suas complicações.

Ao passo em que isto acontece, a entidade da sociedade civil se enfraquece. Ao não se renovar e angariar membros do meio social para seu propósito, distancia-se de seus objetivos iniciais e perde-se numa estrutura administrativa inócua.

Mas não é só. O enfraquecimento abre portas para o desvirtuamento das finalidades. Não raras vezes, interesses escusos (públicos ou privados) inserem-se no meio da entidade da 
sociedade civil e a corrompe, muitas vezes irreversivelmente. A imagem se desgasta e não se renova, levando muitas vezes ao encerramento daquela iniciativa social.

Igualmente, o desamparo logístico é ausência crucial, especialmente nas menores organizações da sociedade civil. Uma vez que estas originam-se de uma "ideia" ou "objetivo", não raramente chegam a um ponto em que sua estruturação exige um conhecimento que não têm. A este momento, cabe ao Poder Público o apoio logístico, o qual, salvo em recentíssimas legislações, jamais foi pensado ou ao mesmo idealizado. Até pouco, o suporte financeiro era o máximo que se alcançava para estas entidades.

Não obstante, falou-se até agora de obstáculos gerais da sociedade civil nacional. Porém, quando se fala de obstáculos advindos de uma sociedade multicultural, acrescenta-se anseios modernos diversos a um quadro já desordenado.

Quando se discute um multiculturalismo, fala-se de vários setores sociais advindos de diversas culturas, as quais por sua vez apresentam problemáticas diametralmente opostas. E por não convergirem (o que é a certo ponto natural), também não se auxiliam. $\mathrm{O}$ tamanho de cada setor social se reduz, e com isto as organizações da sociedade civil daí provindas.

Ou seja, está se falando de um adicional numa conjuntura já caótica. Quando não se verifica apoio logístico ou ideológico a um campo da sociedade civil, diminui-se a efetividade. Quando esta sociedade civil divide-se em face das várias culturas nela existentes, diminui-se a abrangência e representação. E com estes pontos somados, encontra-se um grande obstáculo a ser enfrentado por uma sociedade civil já não mais uníssona, com objetivos diferentes.

Não bastasse, o que se observa são inclusive discussões dentro da própria sociedade civil, uma vez que as posições diametralmente opostas não poucas vezes trazem conflitos entre as entidades.

A busca de soluções, neste contexto, passa não só de uma renovação da relação entre Estado e entidades da sociedade civil, o qual deve dar suporte e incentivo a suas atividades, mas de uma nova interconexão entre as organizações entre si. Deve-se reconhecer a importância multicultural das entidades em seu nascedouro para que então possam desenvolver suas finalidades de maneira coordenada e com suporte real do meio em que se originam. 


\section{CONCLUSÃO}

Ao explanar a figura da administração dialógica no contexto neoconstitucional, observa-se uma nova relação entre Estado e sociedade enquanto mútuos atuantes na busca do interesse coletivo. O diálogo, que aqui ganha nova roupagem, passa a ser não só figura importante mas sim uma verdadeira etapa na construção de uma sociedade democrática.

Isto posto, os atos da Administração têm um novo critério de legitimidade, que é a correspondência do ato com o anseio social. Em nada mais adianta a atuação pública que não esteja em consonância com os atuais interesses comunitários.

A figura de Jürgen Habermas é essencial para compreender esta nova discussão sobre conceitos de legitimidade e democracia, uma vez que assimila em sua teoria do discurso e em seu agir comunicativo os princípios basilares para construção de uma legimitidade democrática nascida do meio social.

Entender todo esta evolução gradativa de conceitos e suas inserções no cenário moderno facilita a compreensão do papel da esfera pública frente à sociedade civil surgida disto. O público e o privado se interligam e se correspondem em busca de uma legitimidade renovada e mais duradoura.

Todavia, as entidades da sociedade civil advindas desta conjuntura, em especial as presentes em nosso ordenamento, enfrentaram e enfrentam imbróglios principalmente ideológicos e logísticos, impeditivos para uma participação efetiva do próprio meio que origina as entidades e obstaculizantes de um crescimento estrutural da própria sociedade civil organizada.

Não bastasse, o cenário multicultural que se apresenta nos tempos atuais também diversifica os âmbitos em que as entidades da sociedade civil irão atuar, e as põe em ponto de colisão com outros interesses sociais opostos.

Para trazer uma melhor solução a estes casos, torna-se imperativo o apoio dúplice. Pelo lado estatal, faz-se mister uma progressiva agenda de apoio logístico às entidades da sociedade civil, para que sejam estruturadas de forma racional e administrativa. Não só isto 
incentiva o crescimento de novas organizações da sociedade civil como contribui para a economia pública, vez que poupa investimentos em setores já abarcados por estas entidades.

Somado a isto, uma melhor fiscalização de atividades das organizações da sociedade civil trará melhor e maior credibilidade àquelas ideologicamente desacreditadas. Com um papel mais ativo no cenário comunitário, haverá perspectivas renovadas para inserção de novos atores sociais.

Por fim, pelo lado da sociedade civil, é importante a compreensão que o multiculturalismo é importante ao passo em que diversos interesses coletivos podem ser postos em foco concomitantemente, e não entrarem em conflito por questões etimológicas. A compreensão pelo meio coletivo da importância destas atuações trará não só um maior enfoque para cada setor da sociedade civil como aumentará a importância dos setores como um todo.

\section{REFERÊNCIAS BIBLIOGRÁFICAS}

ARENDT, Hannah. A Condição Humana. 10 ed. Rio de Janeiro: Forense Universitária, 2007.

ARRIAZA, Ricardo Sol. EI Desafío de la participación ciudadana en el estado democrático de derecho y retos de la participación ciudadana en la gestión de políticas públicas, en espacios institucionales de los estados centroamericanos. $1^{\mathrm{a}}$ ed. San José: Flacso, 2012. Disponível em: < http://unpan1.un.org/intradoc/groups/public/documents/icap/unpan050053.pdf:> Acesso em 15 jul 2017.

BARBIERI, Carla Bertucci. Terceiro Setor: Desafios e Perspectivas Constitucionais. Dissertação de Mestrado apresentada à Pontifícia Universidade Católica de São Paulo/SP. 2006. Disponível em: < https://sapientia.pucsp.br/handle/handle/7596> Acesso em 22 nov 2017.

BARROS, Marcos André de. Habermas e a Democracia: uma teoria crítico-normativa. Recife: NEEPD, 2012.

BINENBOJM, Gustavo. Uma Teoria do Direito Administrativo. Direitos Fundamentais, Democracia e Constitucionalização. Rio de Janeiro: Renovar, 2006. 
BOBBIO, Norberto. A Era dos Direitos. Nova edição. Rio de Janeiro: Elsevier, 2004.

BRANCO, Paulo Gustavo Gonet; COELHO, Inocêncio Mártires; MENDES, Gilmar Ferreira. Curso de Direito Constitucional. 5. ed. São Paulo: Saraiva, 2010.

BRASIL. Instituto Brasileiro de Geografia e Estatística. As Fundações Privadas e Associações sem fins lucrativos no Brasil. Gerência do Cadastro Central de Empresas. Rio de Janeiro: IBGE, 2012.

Ministério do Planejamento. Relações de Parceria entre Poder Público e Entes de Cooperação e Colaboração no Brasil. Secretaria de Gestão. Brasília, Ministério do Planejamento, 2010.

CARVALHO, Kilbare Gonçalves. Direito Constitucional: Teoria do Estado e da Constituição. Direito Constitucional Positivo. 17. ed. Belo Horizonte: Del Rey, 2011.

DI PIETRO, Maria Sylvia Zanella. Direito Administrativo. 23. ed. São Paulo: Atlas, 2010.

FERNANDES, Aline Ouriques Freire; TAVARES NETO, José Querino. Terceiro Setor e Interesses Coletivos: Caminhos para a Cidadania. Revista Serviço Social e Realidade, v. 19, n. 1, 2010. Disponível em: < http: //periodicos.

franca.unesp.br/index.php/SSR/article/view/434> Acesso em 21 mar 2018.

GRAU, Nuria Cunill. Qué há pasado com lo público em los últimos 30 años? Balance y perspectivas. Revista de la CLAD Reforma y Democracia, Caracas, n. 52, fev. 2012. Disponível em: <http://old.clad.org/portal/publicaciones-del-clad/revista-clad-reformademocracia/articulos/052-febrero-2012/Cunill.pdf> Acesso em 02 dez 2017. NAP, 1998.

Repensando o público através da sociedade. Rio de Janeiro. Revan: Brasília, DF:

HABERMAS, Jürgen. Direito e Democracia: entre facticidade e validade Vol I. $2^{\mathrm{a}}$ ed. Rio de Janeiro: Tempo Brasileiro, 2012.

Direito e Democracia: entre facticidade e validade Vol II. $2^{\text {a }}$ ed. Rio de Janeiro: Tempo Brasileiro, 2011.

Revista de Direito Administrativo e Gestão Pública | e-ISSN: 2526-0073 | Salvador | v. 4 | n. 1 | p. 114 131 | Jan/Jun. 2018 
HABERMAS, Jürgen. Verdade e Justificação: ensaios filosóficos. São Paulo: Edições Loyola, 2009.

HABERMAS, Jürgen. Direito e Democracia: entre facticidade e validade Vol I. $2^{\text {a }}$ ed. Rio de Janeiro: Tempo Brasileiro, 2012.

Direito e Democracia: entre facticidade e validade Vol II. $2^{\mathrm{a}}$ ed. Rio de Janeiro: Tempo Brasileiro, 2011.

Mudança Estrutural da Esfera Pública: investigações sobre uma categoria da sociedade burguesa. Tradução Denilson Luís Werle. 1 ed. São Paulo: Editora Unesp, 2014.

IOSCHPE, Evelyn (org.). $3^{\circ}$ Setor: desenvolvimento social sustentado. Rio de Janeiro: Paz e Terra, 2005.

LIMA, Ruy Cirne. Princípios de Direito Administrativo. 7. ed. São Paulo: Malheiros, 2007.

LOPEZ, Francisco e NIETO Y MALLO. La ordenacion legal de las fundaciones. Madrid: La Ley Temas, 2006.

LUNA, Cabra de GARCIA, Lorenzo. La constelación de las entidades no lucrativas: el tecer sector. In ob. Col. El Sector no lucrativo em España. Madrid, 1993.

MEDAUAR, Odete; OLIVEIRA, Gustavo Justino. Consórcios públicos: comentários a Lei 11.107/2005. São Paulo: RT, 2006.

MEIRELLES, Hely Lopes. Direito Administrativo Brasileiro. 35. ed. São Paulo: Malheiros, 2009.

MELLO, Oswaldo Aranha Bandeira de. Princípios Gerais de Direito Administrativo. 2. vol. Rio de Janeiro: Forense, 1969.

MONCADA, Luís S. Cabral de. Direito Econômico. 4. ed. Coimbra: Coimbra, 2003.

Revista de Direito Administrativo e Gestão Pública | e-ISSN: 2526-0073 | Salvador | v. 4 | n. 1 | p. 114 131 | Jan/Jun. 2018 
NEVES, Marcelo José das. A Constitucionalização do Terceiro Setor e a Legitimidade Democrática da Jurisdição Constitucional. Anais do III Seminário Interinstitucional de Mestrados em Direito da UEL. Londrina, 2012.

OLIVEIRA, Rafael Carvalho Rezende. Novo Perfil de Regulação Estatal: Administração Pública de Resultados e Análise de Impacto Regulatório. Rio de Janeiro: Forense, 2015.

Administração Pública, Concessões e Terceiro Setor. 3. ed. Rio de Janeiro: Forense; São Paulo: Método, 2015.

ORMEROD, Alexandre Rodriguez Bueno. Administração Pública Dialógica e Legitimação da Atuação Administrativa. Rio de Janeiro: Escola de Magistratura do Estado do Rio de Janeiro, 2012. 26 f. Programa de Pós-Graduação. ESMERJ, 2012. Disponível em: < http: //www. emerj. tjrj. jus. br/ paginas/ trabalhos_conclusao/

1semestre2012/trabalhos_12012/alexandreormerod.pdf> Acesso em 20 out 2017.

PAES, José Eduardo Sabo. Fundações, Associações e Entidades de Interesse Social: aspectos jurídicos, administrativos, contábeis, trabalhistas e tributários. 8. ed. Rio de Janeiro: Forense, 2013.

PEREIRA, Luiz Carlos Bresser; SPINK, Peter (orgs.). Reforma do Estado e Administração Pública Gerencial. 7. ed. Rio de Janeiro: FGV, 2006.

PEREIRA, Luiz Carlos Bresser. Reforma do Estado para a Cidadania: A Reforma Gerencial Brasileira na Perspectiva Internacional. São Paulo: ed. 34, Brasília: ENAP, 1998.

. A Reforma Gerencial do Estado de 1995. Revista de Administração Pública, Lisboa, jul 2000, vol 34, n. 4. Disponível em: <http: // www. bresserpereira.org.br/ papers/ 2000/81RefGerenc1995-INA.pdf> Acesso em 10 dez 2017.

PORTO, Éderson Garin. Administração Dialógica e o Direito Fundamental à Boa Administração. Páginas de Direito. Disponível em:

$<$ http://www.tex.pro.br/index.php/artigos/316-artigos-ago-2015/7326-administracaodialogica-e-o-direito-fundamental-a-boa-administracao> Acesso em 20 dez 2017.

REZENDE, Isan de Oliveira. Terceiro setor: a nova fronteira do terceiro milênio. Brasília: Instituto Yacaré, 2000. 
SALOMÃO FILHO, Calixto. Regulação da atividade econômica (princípios e fundamentos jurídicos). 2. ed. São Paulo: Malheiros, 2008.

SAMPAIO, José Adércio Leite. Teoria da Constituição e dos Direitos Fundamentais. Belo Horizonte: Del Rey, 2013.

SARLET, Ingo Wolfgang. A eficácia dos direitos fundamentais: uma teoria geral dos direitos fundamentais na perspectiva constitucional. 11. ed. Porto Alegre: Livraria do Advogado, 2011.

SOARES, Gabriela Mansur. Administração Pública Dialógica na Constituição de 1988: a construção do interesse público com a participação da sociedade civil. XVII Congresso Nacional do CONPEDI, Brasília: UNB, 2008. Disponível em: < http://www.publicadireito.com.br/conpedi/manaus/arquivos/anais/brasilia/07_823.pdf> Acesso em 19 dez 2017.

SOUZA, José Crisóstomo de (org.). Filosofia, Racionalidade, Democracia: os debates Rorty e Habermas. São Paulo: Editora UNESP, 2005.

TACHIZAWA, Takeshy. Organizações não governamentais e Terceiro Setor: criação de ONGs e estratégias de atuação. 3. ed. São Paulo: Atlas, 2007.

VITULLO, Gabriel Eduardo (org.). A ideologia do "Terceiro Setor": ensaios críticos. Natal: EDUFRN, 2012. 